\title{
Detection of tumor-specific marker for minimal residual disease in multiple myeloma patients
}

\author{
Lenka Sedlarikovaa , Lena Kubiczkova a, , Fedor Kryukova, Jana Pelcovab , Zdenek Adam ${ }^{b}$, Ludek Pour ${ }^{b}$, \\ Roman Hajek ${ }^{\mathrm{a}, \mathrm{c}}$, Sabina Sevcikova ${ }^{\mathrm{a}, \mathrm{c}}$
}

\begin{abstract}
Aims. Multiple myeloma (MM), the second most common hematological cancer, is a lymphoproliferative disease of terminally differentiated $B$ lymphocytes characterized by expansion of monoclonal plasma cells. With the introduction of new drugs, MM has become a hard-to-treat disease. The aim of treatment is clinical remission and eradication of clinical manifestations but most MM patients eventually relapse. For this reason, more accurate monitoring of remission and relapse using molecular biology techniques is at the center of attention.

Methods. For monitoring, we used allele-specific PCR and quantitative real-time PCR based on specific detection of VDJ immunoglobulin heavy chain gene rearrangement of clonal cells for monitoring. The hypervariable region of Ig $\mathrm{H}$ rearrangement is used for detection of minimal residual disease (MRD) in MM as this sequence is used for allele-specific primers and probe design. This technique is a complementary tool for flow cytometry in MRD detection; however, it has not been established in the Czech Republic so far.

Results. Qualitative and quantitative MRD detection was performed in 50\% (5/10) patients and qualitative MRD detection in another 3 oligoclonal patients.

Conclusions. Next to flow cytometry, detection of MRD by qPCR is a viable option and has been introduced in the Czech Republic.

Key words: multiple myeloma, minimal residual disease, tumor-specific marker, ASO PCR, RQ-PCR, IgH gene rearrangement

Received: January 16, 2014; Accepted with revision: June 6, 2014; Available online: June 23, 2014

http://dx.doi.org/10.5507/bp.2014.035

${ }^{a}$ Babak Myeloma Group, Department of Pathological Physiology, Faculty of Medicine, Masaryk University Brno, Czech Republic ${ }^{b}$ Department of Internal Medicine - Hematooncology, University Hospital Brno

'Department of Clinical Hematology, University Hospital Brno

Corresponding author: Sabina Sevcikova, e-mail: sevcik@med.muni.cz
\end{abstract}

\section{INTRODUCTION}

Multiple myeloma (MM) is a plasma cell malignancy that is ranked among $\mathrm{B}$ lymphoproliferative neoplasias by the World Health Organization ${ }^{1}$. MM is a complex disease characterized by accumulation of clonal malignant plasma cells $(\mathrm{PC})$ in the bone marrow (BM) together with production of monoclonal immunoglobulins or light/ heavy chains, resulting in clinical manifestation of the disease. Osteolysis, hypercalcemia, anemia, immune system impairment and renal insufficiency are among the most common clinical manifestations of MM (ref. $\left.{ }^{2,3}\right)$.

With the introduction of new drugs and use of autologous stem cell transplantation, $\mathrm{MM}$ is slowly turning into a chronic disease. The aim of the treatment is hematological remission and eradication of clinical manifestations. Nevertheless, most MM patients eventually relapse ${ }^{3}$. This implies that not all clonogenic malignant cells had been killed and that the residue of malignant cells persisting even after treatment contributes to recurrence of the disease.

For this reason, more accurate monitoring of remission and relapse by molecular biology techniques is important. One of these techniques is allele-specific (ASO) PCR and a real-time quantitative PCR (RQ-PCR) based on analysis of junctional regions of rearranged immunoglobulin heavy chain (IGH) gene $e^{4}$. The hypervariable region of $\mathrm{IgH}$ rearrangement is used as a tumor marker for detection of minimal residual disease in MM. Determination of such marker and its sequence analysis further allows for allele-specific (ASO) primers and probe design ${ }^{5}$.

MRD detection using PCR has major advantages because of its sensitivity, accuracy, reproducibility, need of small amount of DNA and widespread and irreplaceable use in retrospective studies. On the other hand, PCR methods are more complex, expensive, take more time and allow detection of only one clone that was present at the time of diagnosis ${ }^{6}$. However, detection of tumor marker by PCR has a wide application for clinical evaluation of patients, for early relapse detection or for quantification of tumor contamination in healthy hematopoietic cells for autologous transplantation ${ }^{7}$.

The use of flow cytometry (FC) for MRD detection appears to have prognostic significance as well $1{ }^{6,7}$. One current approach is MRD detection using an 8-color polychromatic FC. This technique is also able to differentiate the expression of immunoglobulin light chain (IgL) $\kappa$ or $\lambda\left(\right.$ ref. $\left.^{8,9}\right)$. MRD detection via FC is applicable in 
approximately $90 \%$ of MM patients, which is important for routine practice ${ }^{6}$. The significance of FC use in MRD detection was shown in the large studies of Paiva et al. In these studies, patient treatment response was evaluated via immunofixation, serum free light chain, multiparameter FC immunophenotyping and FC together with assessment of high-risk cytogenetics ${ }^{10,11}$.

Unfortunately, there has never been a comparative study of PCR vs. FC in a large cohort of patients treated with widely used treatment regimens. Nevertheless, according to some smaller studies - both techniques have comparable prognostic significance. Nowadays, they are considered to be complementary tools for MRD monitoring $^{6,12}$.

Currently, new technologies for the detection of tumor-specific marker are emerging, such as droplet digital PCR or next generation sequencing (NGS) (ref. ${ }^{13,14}$ ). However, the qualitative and quantitative detection of tumor-specific marker by ASO-PCR is still the golden standard technique ${ }^{7}$. Nevertheless, the technique of MMspecific marker detection using ASO-PCR has not been established in the Czech Republic so far. Therefore, the aim of this work was to introduce allele-specific qualitative and quantitative detection of MM-related marker by PCR on BM and peripheral blood samples of MM patients in our laboratory for further MRD assessment.

\section{MATERIAL AND METHODS}

\section{Patients and samples}

Frozen genomic DNA (gDNA) derived from mononuclear cells from BM (BMMC) of 10 newly diagnosed and relapsed MM patients diagnosed between 2006 and 2007 at the Faculty Hospital Brno was included in the study (Table 1). For 6 patients, gDNA samples of mononuclear cells from peripheral blood (PBMC) at the time of relapse were available, for 2 other patients, gDNA samples of BMMC at the time of relapse were available. gDNA was isolated using phenol-chloroform extraction, and stored at $-20{ }^{\circ} \mathrm{C}$. Also, gDNA from PBMC of 10 healthy donors was included in the study. This gDNA was isolated using QIAamp DNA Mini Kit (Qiagen). All samples were included only after patients signed the informed consent approved by Ethical committee of the hospital.

\section{Amplification and sequencing of tumor-specific IgH gene rearrangement}

To identify tumor-related $\mathrm{IgH}$ rearrangements, $500 \mathrm{ng}$ of gDNA was PCR-amplified using sets of primers for IgH variable (V), diversity (D), and joining (J) gene segments with $2 \mathrm{mM}$ dNTP, $20 \mathrm{mM} \mathrm{MgCl}$, 5x Buffer and GoTaq Flexi DNA Polymerase (Promega) (ref. ${ }^{15,16}$ ). The reaction was carried out for initial denaturation at $94{ }^{\circ} \mathrm{C}$ for $1 \mathrm{~min}$ and then 33 (40) cycles of denaturation at $94{ }^{\circ} \mathrm{C}$ for 30 $\mathrm{s}$, annealing at $62{ }^{\circ} \mathrm{C}$ for $30 \mathrm{~s}$, and extension at $72{ }^{\circ} \mathrm{C}$ for $30 \mathrm{~s}$, with a final extension of 10 minat $72{ }^{\circ} \mathrm{C}$ (ref. ${ }^{17}$ ). PCR products were then run on $2 \%$ agarose gels to find clonal products. Clonal PCR products were excised and purified using MinElute Gel Extraction Kit, QIAquick
PCR Purification Kit or QIAquick Gel Extraction Kit (all Qiagen) and further sequenced. Purified PCR fragments were sequenced using BigDye Terminator v3.1 Cycle Sequencing Kit on ABI3130 DNA Sequencer (Applied Biosystems). The relevant $\mathrm{VH}$ family or $\mathrm{JH}$ consensus primers were used as sequencing primers to obtain the sequence information (Table 2) (ref. ${ }^{15,16,18}$ ).

\section{ASO primers design and nested PCR amplification of tumor-specific IgH gene rearrangement}

Patient-specific ASO primers of CDRIII region were designed using IMGT/V-QUEST (http://www.imgt.org/) and PrimerBlast (http://www.ncbi.nlm.nih.gov/tools/ primer-blast/) and synthesized by Eurofins MWG Operon (Ebersberg, Germany) (ref. ${ }^{19}$ ). Nested PCR amplification using ASO primers for each $\mathrm{IgH}$ sequence identified earlier were performed using $2 \mathrm{mM}$ dNTP, $20 \mathrm{mM} \mathrm{MgCl}$, 5x Buffer and GoTaq Flexi DNA Polymerase (Promega). PCR was performed as initial denaturation at $94{ }^{\circ} \mathrm{C}$ for $1 \mathrm{~min}$, and then 33 cycles of amplification at $94{ }^{\circ} \mathrm{C}$ for $30 \mathrm{~s} 58-62{ }^{\circ} \mathrm{C}$ (dependent on specific ASO primer Tm) for $30 \mathrm{~s}$, and $72{ }^{\circ} \mathrm{C}$ for $30 \mathrm{~s}$, with final extension of $10 \mathrm{~min}$ at $72{ }^{\circ} \mathrm{C}$. PCR products were run on $2 \%$ agarose gels ${ }^{17}$.

Table 1. Patient's baseline characteristics.

\begin{tabular}{lc}
\hline Total number of patients & 10 \\
Sex: male/female & $5 / 5$ \\
Average age at diagnosis (range) [years] & $64(52-81)$ \\
ISS stage: I-II-III (\%) & $60-30-10$ \\
Durie-Salmon stage: I-II-III (\%) & $40-0-60$ \\
Ig isotype: IgG-IgD-LC only (\%) & $70-10-20$ \\
Monoclonal Ig (g/l) & $34.7(0-79.8)$ \\
Plasma cells infiltration of bone marrow (\%) & $31.1(10.0-81.6)$ \\
\hline
\end{tabular}

Table 2. Sequences of the consensual primers used for $\operatorname{IgH}$ rearrangement detection.

(Symbols: $\mathrm{R}=\mathrm{A} / \mathrm{G}, \mathrm{Y}=\mathrm{T} / \mathrm{C}, \mathrm{S}=\mathrm{G} / \mathrm{C}, \mathrm{K}=\mathrm{G} / \mathrm{T}$ ).

\begin{tabular}{ll}
\hline Primer & Sequence (5'-3') \\
\hline VH1FS & CAGGTGCAGCTGGTGCARYCTG \\
VH2FS & CAGRTCACCTTGAAGGAGTCTG \\
VH3FS & GAGGTGCAGCTGGTGSAGTCYG \\
VH4aFS & CAGSTGCAGCTGCAGGAGTCSG \\
VH4bFS & CAGGTGCAGCTACARCAGTGGG \\
VH5FS & GAGGTGCAGCTGKTGCAGTCTG \\
VH6FS & CAGGTACAGCTGCAGCAGTCAG \\
VHFR2-1 & CTGGGTGCGACAGGCCCCTGGACAA \\
VHFR2-2 & TGGATCCGTCAGCCCCCAGGGAAGG \\
VHFR2-3 & GGTCCGCCAGGCTCCAGGGAA \\
VHFR2-4 & TGGATCCGCCAGCCCCCAGGGAAGG \\
VHFR2-5 & GGGTGCGCCAGATGCCCGGGAAAGG \\
VHFR2-6 & TGGATCAGGCAGTCCCCATCGAGAG \\
VHFR2-7 & TTGGGTGCGACAGGCCCCTGGACAA \\
JHD & ACCTGAGGAGACGGTGACCAGGGT \\
\hline
\end{tabular}


PCR products from ASO PCR were also sequenced as described previously, to ensure the detection of the same sequence.

\section{Design of probes for RQ-PCR}

For RQ-PCR analysis of tumor-related sequence $\mathrm{H}$-chain $\mathrm{V}$ - region $(\mathrm{VH})$ family-specific consensus reverse probes (called L-VH1 to L-VH6) derived from the germline sequence FR3 and designed for use in RQ-PCR in childhood ALL were used ${ }^{20}$. Because of the high rate of somatic hypermutations occurring in MM, novel probes were required. The new specific IgH probes were designed according to recommendations of Ladetto et al. ${ }^{17}$ (Eurofins MWG Operon, Ebersberg, Germany) and la-

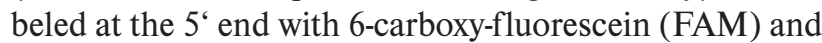
6 carboxytetramethyl rhodamine (TAMRA) at the $3^{\prime}$ end. RQ-PCR reaction was performed in $25 \mu \mathrm{L}$ with $500 \mathrm{ng}$ of patient's gDNA using 1x TaqMan Gene Expression MasterMix (Life Technologies), 10 pmol of each patient's specific ASO primer, 5 pmol specific $\mathrm{IgH}$ probe. Reactions were incubated in a 96-well optical plate at 50 ${ }^{\circ} \mathrm{C}$ for $2 \mathrm{~min}, 95{ }^{\circ} \mathrm{C}$ for $10 \mathrm{~min}$, followed by 42 cycles at $95^{\circ} \mathrm{C}$ for $15 \mathrm{~s}$ and $60{ }^{\circ} \mathrm{C}$ for $1 \mathrm{~min}$. All reactions were run in triplicate on 7500 Real-Time PCR System. Standards for RQ-PCR were obtained by cloning the tumor-specific IgH region with the TOPO TA cloning Kit (Invitrogen). A variable number of white-positive colonies (colonies with correct plasmid insertion) were grown overnight in Luria-Bertani broth containing $50 \mathrm{mg} / \mathrm{mL}$ ampicillin. Plasmid DNA was purified using QIAprep Spin Miniprep Kit (Qiagen). Standard curves were prepared by ten- fold serial dilutions of plasmid in gDNA obtained from healthy donors according to the European Study Group on MRD Detection in ALL (ESG-MRD-ALL criteria) $\left(\right.$ ref. $\left.{ }^{21}\right)$. Then, the quantitative analysis of tumor-specific sequence was related to the reference human RNase P gene (Applied Biosystems).

Monoclonality of the specific sequence was verified by sequence analysis of PCR product from single colonies cloned with specific VDJ gene rearrangement of $\mathrm{IgH}$.

\section{RESULTS}

gDNA samples of ten patients obtained from BMMC were used for introduction of tumor-specific marker identification by PCR. Fifty percent of the patients (5/10) were suitable both for qualitative and quantitative tumor marker detection. In 30\% (3/10) of patients, the sequence was not clear and they were assessed as oligoclonal. This technique was unsuccessful in $20 \%$ (2/10) of our patients (Table 3).

\section{Tumor-specific IgH gene rearrangement amplification and sequence analysis}

The tumor-specific marker was established for $80 \%$ (8/10) patients by PCR with consensual primers (derived from FR1 and FR2 conservative regions). IGHV3 allele was present in $30 \%(3 / 10)$ of patients, IGHV2 in $10 \%$ $(1 / 10)$ and IGHV4 in $10 \%(1 / 10)$ of patients. Sequences were analyzed using bioinformatic tool IMGT/V-QUEST for CDR2/3 hypervariable region evaluation. Only pro-

Table 3. A summary of individual steps of PCR detection of tumor-specific marker in MM (nd - not done).

\begin{tabular}{|c|c|c|c|c|c|c|}
\hline \multirow{2}{*}{ Patient } & \multicolumn{3}{|c|}{ ASO PCR } & \multicolumn{3}{|c|}{ qPCR } \\
\hline & alelle & ASO primers & PCR II & ASO probes & standard curves & qPCR \\
\hline 1 & IGHV2 & done & done & done & done & quantifiable \\
\hline 2 & IGHV3 & done & done & done & done & quantifiable \\
\hline 3 & oligoclonal & done & done & nd & nd & nd \\
\hline 4 & IGHV4 & done & done & done & done & out of quantitative range \\
\hline 5 & IGHV3 & done & done & done & done & quantifiable \\
\hline 6 & oligoclonal & done & done & nd & nd & nd \\
\hline 7 & oligoclonal & done & done & nd & nd & nd \\
\hline 8 & IGHV3 & done & done & done & done & quantifiable \\
\hline 9 & nd & nd & nd & nd & nd & nd \\
\hline 10 & nd & nd & nd & nd & nd & nd \\
\hline
\end{tabular}

Table 4. Results of RQ-PCR detection of tumor-specific marker in MM.

\begin{tabular}{clcccl}
\hline Patient & Status & ASO probe & RNase P & Malignant cells./ $10^{6}$ healthy cells & Conclusion \\
\hline 1 & 1. relapse & 14.4 & 43348 & 662,1 & positive, quantifiable \\
& diagnosis & 4239 & 37390 & 226726,9 & positive, quantifiable \\
2 & 1. relapse & 1.7 & 29462 & 114,4 & positive, quantifiable \\
4 & 1. relapse & 3.9 & 3331,6 & 2327 & positive, out of quantitative range \\
5 & diagnosis & 21963 & 59797 & 734598,4 & positive, quantifiable \\
8 & 1. relapse & 68 & 3348,1 & 40606,7 & positive, quantifiable \\
\hline
\end{tabular}


ductive IgH rearranged sequences (in frame junctions, no stop codon) were used for further work.

Monoclonality of the specific sequence was verified by direct sequence analysis of cloned PCR product from plasmid in bacteria in 5 patients. In 3 remaining oligoclonal patients, we identified $\geq 3$ different clones.

\section{ASO primer design, testing and qualitative PCR for tumor-specific marker detection}

ASO primers were designed for 5 patients with successfully obtained molecular marker and for 1 clone of 3 oligoclonal patients (Supplementary table S1). In 7 patients, ASO primers were designed according to patient's specific gDNA sequence and in 1 case, we used plasmid sequence with cloned VDJ region for primer design, because of higher quality of the sequence. Qualitative crossreaction was performed to verify specificity of designed ASO primers to only one patient. Six out of 8 pairs of primers were specific for only one patient.

Qualitative PCR with designed ASO primers was performed on gDNA diagnostic samples from 5 patients with monoclonal sequence. The original clone was present in follow-up samples of 3 patients at the time of relapse. For the other 2 patients, samples were not available. Moreover, PCR was performed on follow-up samples at the time of relapse for 3 oligoclonal patients as well, where 1 of the original clones was successfully detected in 1 oligoclonal patient relapse sample.

\section{ASO probe design and RQ-PCR for tumor-specific marker detection}

Quantitative detection of MRD was performed on 5 monoclonal patients. In these patients, we were able to clone monoclonal sequence into plasmids in order to obtain standard curves (Supplementary table S2, Fig. S1). These standard curves fulfilled ESG-MRD-ALL criteria ${ }^{21}$. The detection was not performed for oligoclonal patients, as the plasmids carried different inserts of the VDJ rearrangements.

For RQ-PCR analysis of tumor-related marker, we started with specific consensus probes derived from the germline sequence of the FR3 region and designed for use in RQ-PCR in childhood ALL (ref. ${ }^{20}$ ). These consensus probes were used in 2/5 patients (LVH2 and LVH3 probes) and were fully complementary with patient's sequences. Because of high rate of somatic hypermutations occurring in MM, we designed new probes according to recommendations of Ladetto et al. for 3/5 patients (Supplementary table S3) ( ref. $^{17}$ ).

Quantification was based on human RNase P reference gene. The RQ-PCR reaction was successful for all 5 patients. Four samples were assessed as positive (concordant with qualitative PCR results) and quantifiable (Table 4). In one patient, MRD was assessed as positive, out of quantitative range. The RQ-PCR sensitivity was up to $10^{-6}$

\section{DISCUSSION}

The aim of the work was to introduce MM-related marker identification for further MRD detection by PCR in our laboratory as a complementary tool for MRD assessment by FC. For the purpose of method introduction, we used retrospective patient samples from the time of diagnosis and relapse in order to confirm presence of clonogenic cells and their tumor-specific marker.

MRD monitoring is important for identification of patients at increased risk of relapse and plays a key role in treatment response assessment in clinical trials ${ }^{7}$. Unlike MRD detection by FC which can be applied in approximately $90 \%$ of patients with MM thus allowing routine examination, approaches based on PCR are more complex and can be applied in approximately $75 \%$ of patients with MM because of the extensive heterogeneity of the disease and presence of several MM clones at the time of diagnosis $^{6}$. Although PCR is less applicable than FC, it is a powerful technique for treatment efficacy assessment and risk stratification in MM (ref. ${ }^{17,22-25}$ ). In this study, with the PCR detection of clonogenic cells, we were able to obtain qualitative assessment in $80 \%$ of patients and quantitative data, important for serial monitoring, in 50\% of patients (Table 3 ).

We preferentially used FR1 or FR2 derived primers, as we need to obtain sequence of variable regions CDR2/3. Therefore, FR1/2 derived primers allowed us to obtain sequence that was shorter and more suitable for our analysis compared to using L derived primers ${ }^{15,26}$. Further, we did not use FR3 derived primers because the sequences obtained after such amplification are too short which increases the risk of false positive results. For comparison, Owen et al. used FR3 derived primers although this approach allowed detection of specific $\mathrm{IgH}$ rearrangement only in $56 \%$ of patients ${ }^{27}$. However, all of the above mentioned approaches are possible, as described previously by van Dongen et al. ${ }^{16}$.

In our case, the successfully identified VDJ rearrangements were in accordance with average frequency of $\mathrm{VH}$ variants $^{16,28}$. Although it is possible to perform PCR reaction with several primer families, in approximately $20 \%$ cases we were not able to identify specific VDJ rearrangement sequence. This was most likely due to the presence of somatic hypermutations and subsequent loss of primer binding sites in patient-specific sequence given by extensive heterogeneity in MM clones ${ }^{4,7,15}$. On average, there are $8 \%$ of mutated nucleotides of VDJ rearrangement sequence in MM patients ${ }^{29,30}$; however only $2 \%$ in chronic lymphocytic leukemia (CLL) and 4\% in follicular lymphoma ${ }^{7}$.

As the average homology of a patient's sequence with germline sequence is $92.2 \%$, the annealing ability of primers derived from consensus regions of $\mathrm{IgH}$ is limited ${ }^{30}$. In our case, the primer design was successful for all patients with monoclonal sequences $(5 / 10)$, and for one of the clones of all patients with oligoclonal sequence (3/10). In $1 / 10$ case, we used sequence obtained from the plasmid with cloned hypervariable region for the primer design, as was previously described by Voena et al. ${ }^{15}$. 
We also verified specificity of designed primers to only one patient by qualitative cross-annealing reaction, as was shown in 6/8 designed pairs of primers. Specific ASO primers are used for tumor marker identification and its further detection during the patient follow-up. However, we cannot exclude annealing of specific ASO primers on different MM patient. The CDR2 and CDR3 regions are relatively short; therefore, there is a high probability of similar motifs repetition. Nevertheless, the crucial thing is that designed ASO primers are not able to amplify healthy DNA; primers have to be specific for MM (ref. ${ }^{31}$ ).

The method used for MRD quantification is RQ-PCR with ASO primers and probes. The fluorescence signal is provided by probe derived from the more conservative region of the VDJ rearrangement (FR3). First, the specific probe is chosen from previously designed probes for use in real-time PCR in childhood ALL (ref. ${ }^{20}$ ). Since these probes can be used for several patients, there was a significant reduction in the price of this method compared to methods using patient-specific probes ${ }^{17,32}$.

Concerning the probes, we confirmed results of Ladetto et al., who analyzed the effect of mismatch between probe sequence and sequence of the patient. Probe was unsuccessful every time in the case of at least three mismatches. In contrast, probe was always successful in the case of no or one mismatch. And in the case of two mismatches, the success of probe annealing was in the type of substitution: $\mathrm{G} / \mathrm{C}$ (strong interaction); $\mathrm{A} / \mathrm{T}$ (weak interaction) (ref. ${ }^{17}$ ).

In our study, the RQ-PCR was successful for all 5 monoclonal patients. Four samples were assessed as positive (concordant with qualitative PCR results) and quantifiable. In one patient, MRD was assessed as positive, but out of quantitative range. The rate of ASO RQ-PCR is considerably variable because of significant heterogeneity of MM cells but approximately ranging from $30 \%$ to over $80 \%$ (ref. ${ }^{22,23,32,33}$ ). In the remaining 3 oligoclonal patients, we were not able to perform the quantification because of the oligoclonal nature of the disease. In these types of samples, it is not very feasible to prepare standard curves necessary for the MRD quantification.

The main advantage of MRD detection by RQ-PCR is its high sensitivity. The sensitivity is dependent on the specific ASO probe hybridisation and therefore also on the clone-specific IGHV sequence used for ASO primer and probe design ${ }^{17}$. Therefore, for this reason, we cannot reach the same sensitivity for all patients. In our work, we were able to reach RQ-PCR sensitivity of at least $10^{-4}$ and up to $10^{-6}$. This result is in accordance with other studies since most studies dealing with RQ-PCR detection of MRD also reach sensitivity between $10^{-4}$ and $10^{-6}$ (ref. ${ }^{7,21,33}$ ).

Despite all the risks and complications, PCR based MRD detection has wide application, such as quantification of tumor contamination in healthy hematopoietic cells for autologous transplantation or following the dynamics of clonogenic cells and activity of the tumor load $^{34,35}$. Its quantification is useful for treatment response and prognostic assessment as well as for early relapse detection $^{17,22,23,36,37}$.

\section{CONCLUSION}

Standard techniques used for remission evaluation are able to give only superficial information about the treatment efficiency because of their limited sensitivity. There is a need for more sensitive methods to gather more detailed insight and detection of small tumor cell residues. One of these methods is PCR detection of tumor-specific marker for MRD. This approach has some limitations because of significant heterogeneity of tumor plasma cells and presence of somatic hypermutations in MM. For this reason, it is only successful in some patients and also molecular biological approaches of MM-related marker detection are provided only in a limited number of laboratories. However, we successfully managed to establish this method at both qualitative and quantitative level in MM patients for the first time in the Czech Republic.

Acknowledgement: We would like to thank all the patients, their caregivers and our data-managers for allowing us to do this work. We would also like to thank John B. Smith for proofreading the manuscript.

This work was supported by grants of The Ministry of Education, Youth and Sports: MSM0021622434, grants of the Ministry of Health, Czech Republic - IGA NT11154, NT12130, NT14575, grant of the Masaryk University MUNI/C/0963/2012 and grant of the Grant Agency of the Czech Republic GAP304/10/1395.

Author contribution: RH, SS: mnuscript writing; LS, LK: experiment design; FK: data analysis; JP, LP, ZA: clinical data collection.

Conflict of interest statement: The authors state that there are no conflicts of interest regarding the publication of this article.

\section{REFERENCES}

1. Harris NL, Jaffe ES, Diebold J, Flandrin G, Muller-Hermelink HK, Vardiman J, Lister TA, Bloomfield CD. World Health Organization classification of neoplastic diseases of the hematopoietic and lymphoid tissues: report of the Clinical Advisory Committee meeting-Airlie House, Virginia, November 1997. J Clin Oncol 1997;17:3835-49.

2. Anderson KC, Carrasco RD. Pathology of myeloma. Annu Rev Pathol Mech Dis 2011;6:249-74.

3. Hájek R, Adam Z, Ščudla V, Maisnar V, Bačovský J, Špička I, Krejčí $M$, Kessler P, Minařík J, Sandecká V, Radocha J. Diagnostika a léčba mnohočetného myelomu: Doporučení vypracované Českou myelomovou skupinou, Myelomovou sekcí České hematologické společnosti a Slovenskou myelómovou spoločností pro diagnostiku a léčbu mnohočetného myelomu. Transfuze Hematol dnes 2012;18(Suppl 1):1-89.(In Czech).

4. Bakkus MH, Heirman C, Van Riet I, Van Camp B, Thielemans K. Evidence that multiple myeloma Ig heavy chain VDJ genes contain somatic mutations but show no intraclonal variation. Blood 1992;80(9):2326-35.

5. Voena C, Ladetto M, Astolfi M, Provan D, Gribben JG, Boccadoro M, Pileri A, Corradini P. A novel nested-PCR strategy for the detection of rearranged immunoglobulin heavy-chain genes in B cell tumors. Leukemia 1997;11(10):1793-98.

6. Sarasquete ME, García-Sanz R, González D, Martínez J, Mateo G, Martínez P, Ribera JM, Hernández JM, Lahuerta JJ, Orfão A, González $M$, San Miguel JF. Minimal residual disease monitoring in multiple myeloma: a comparison between allelic-specific oligonucleotide 
real-time quantitative polymerase chain reaction and flow cytometry. Haematologica 2005;90(10):1365-72.

7. Davies FE, Rawstron AC, Owen RG, Morgan GJ. Minimal residual disease monitoring in multiple myeloma. Best Pract Res Clin Haematol 2002;15(1):197-222.

8. Říhová L, Varmužová T, Suská R, Zarbochová P, Penka M, Hájek R. Monitoring of minimal residual disease in multiple myeloma patients: Development and standardization of method. In 6th Myeloma workshop: Modern technologies in research of monoclonal gammopathies. Brno, 2011.Brno:Masarykova univerzita.s.8-9. ISBN 978-80-210-5589-6.

9. van Dongen JJ, Lhermitte $L, B$ B̈ttcher $S$, Almeida J, van der Velden VH, Flores-Montero J, Rawstron A, Asnafi V, Lécrevisse $Q$, Lucio $P_{r}$ Mejstrikova E, Szczepański T, Kalina T, de Tute R, Brüggemann M, Sedek L, Cullen M, Langerak AW, Mendonça A, Macintyre E, MartinAyuso $M$, Hrusak $O$, Vidriales MB, Orfao A; EuroFlow Consortium (EU-FP6, LSHB-CT-2006-018708). EuroFlow antibody panels for standardized n-dimensional flow cytometric immunophenotyping of normal, reactive and malignant leukocytes. Leukemia 2012;26(9):1908-75.

10. Paiva B, Martinez-Lopez J, Vidriales MB, Mateos MV, Montalban MA Fernandez-Redondo E, Alonso L, Oriol A, Teruel Al, de Paz R, Laraña JG, Bengoechea E, Martin A, Mediavilla JD, Palomera L, de Arriba F, Bladé J, Orfao A, Lahuerta JJ, San Miguel JF. Comparison of immunofixation, serum free light chain, and immunophenotyping for response evaluation and prognostication in multiple myeloma. $J$ Clin Oncol 2011;29(12):1627-33.

11. Paiva B, Gutiérrez NC, Rosiñol L, Vídriales MB, Montalbán MÁ, Martínez-López J, Mateos MV, Cibeira MT, Cordón L, Oriol A, Terol MJ, Echeveste MA, de Paz R, de Arriba F, Palomera L, de la Rubia J, DíazMediavilla J, Sureda A, Gorosquieta A, Alegre A, Martin A, Hernández MT, Lahuerta JJ, Bladé J, San Miguel JF; PETHEMA/GEM (Programa para el Estudio de la Terapéutica en Hemopatías Malignas/Grupo Español de Mieloma) Cooperative Study Groups. High-risk cytogenetics and persistent minimal residual disease by multiparameter flow cytometry predict unsustained complete response after autologous stem cell transplantation in multiple myeloma. Blood 2012;119(3):687-91.

12. Lioznov M, Badbaran A, Fehse B, Bacher U, Zander AR, Kröger NM Monitoring of minimal residual disease in multiple myeloma after allo-SCT: flow cytometry vs PCR-based techniques. Bone Marrow Transplant 2008;41(10):913-16.

13. Ladetto $M$, Brüggemann $M$, Monitillo L, Ferrero S, Pepin F, Drandi D, Barbero D, Palumbo A, Passera R, Boccadoro $M$, Ritgen $M$ Gökbuget N, Zheng J, Carlton V, Trautmann H, Faham M, Pott C. Next-generation sequencing and real-time quantitative PCR for minimal residual disease detection in B-cell disorders. Leukemia 2013;doi: 10.1038/leu.2013.375.[Epub ahead of print]

14. Drandi D, Kubiczkova L, Dani N, Ferrero S, Barberio D, Monitillo L, Barbero D, Mantoan B, Genuardi E, Ghione P, Gambella M, Ruggeri M, Seraci E, Omedè P, Hajek R, Boccadoro $M$, Palumbo A, Cortelazzo $S$, Inghirami G, Ladetto M. Improved IgH-based MRD detection by using DROPLET DIGITAL PCR: a comparison with real time quantitative PCR in MM and MCL. In American Society of Hematology: Annual Meeting. New Orleans, 2013

16. van Dongen JJ, Langerak AW, Brüggemann $M$, Evans $P A$, Hummel $M$, Lavender FL, Delabesse E, Davi F, Schuuring E, García-Sanz R, van Krieken JH, Droese J, González D, Bastard C, White HE, Spaargaren M, González M, Parreira A, Smith JL, Morgan GJ, Kneba M, Macintyre EA. Design and standardization of PCR primers and protocols for detection of clonal immunoglobulin and T-cell receptor gene recombinations in suspect lymphoproliferations: report of the BIOMED-2 Concerted Action BMH4-CT98-3936. Leukemia 2003;17(12):2257317.

17. Ladetto M, Donovan JW, Harig S, Trojan A, Poor C, Schlossnan R Anderson KC, Gribben JG. Real-Time polymerase chain reaction of immunoglobulin rearrangements for quantitative evaluation of minimal residual disease in multiple myeloma. Biol Blood Marrow Transplant 2000;6(3):241-53.

18. Compagno M, Mantoan B, Astolfi M, Boccadoro M, Ladetto M. Real-Time Polymerase Chain Reaction of Immunoglobulin Rearrangements for Quantitative Evaluation of Minimal Residual Disease in Myeloma. Methods Mol Med. In: Brown RD, Joy Ho P. 2005 Multiple Myeloma: Methods and protocols. New Jersey: Humana Press Inc;2005. p.145-163.
19. Lefranc MP, Giudicelli V, Kaas Q, Duprat E, Jabado-Michaloud J, Scaviner D, Ginestoux C, Clément O, Chaume D, Lefranc G. IMGT, the international ImMunoGeneTics information system. Nucleic Acids Res 2005;33(Database issue):D593-97.

20. Donovan JW, Ladetto M, Zou G, Neuberg D, Poor C, Bowers D, Gribben JG. Immunoglobulin heavy-chain consensus probes for real-time PCR quantification of residual disease in acute lymphoblastic leukemia. Blood 2000;95(8):2651-8.

21. van der Velden VH, Cazzaniga G, Schrauder A, Hancock J, Bader $P_{\text {, }}$ Panzer-Grumayer ER, Flohr T, Sutton R, Cave H, Madsen HO, Cayuela JM, Trka J, Eckert C, Foroni L, Zur Stadt U, Beldjord K, Raff T, van der Schoot CE, van Dongen JJ; European Study Group on MRD detection in ALL (ESG-MRD-ALL). Analysis of minimal residual disease by lg/ TCR gene rearrangements: guidelines for interpretation of real-time quantitative PCR data. Leukemia 2007;21(4):604-11.

22. Bakkus MH, Bouko Y, Samson D, Apperley JF, Thielemans K, Van Camp B, Benner A, Goldschmidt H, Moos M, Cremer FW. Posttransplantation tumour load in bone marrow, as assessed by quantitative ASO-PCR, is a prognostic parameter in multiple myeloma. Br J Haematol 2004;126(5):665-74.

23. Korthals M, Sehnke N, Kronenwett R, Bruns I, Mau J, Zohren F, Haas R, Kobbe G, Fenk R. The level of minimal residual disease in the bone marrow of patients with multiple myeloma before highdose therapy and autologous blood stem cell transplantation is an independent predictive parameter. Biol Blood Marrow Transplant 2012;18(3):423-31.e3.

24. Fenk R, Ak M, Kobbe G, Steidl U, Arnold C, Korthals M, Hünerlitürkoglu A, Rohr UP, Kliszewski S, Bernhardt A, Haas R, Kronenwett R. Levels of minimal residual disease detected by quantitative molecular monitoring herald relapse in patients with multiple myeloma. Haematologica 2004;89(5):557-66.

25. Martinelli G, Terragna C, Zamagni E, Ronconi S, Tosi P, Lemoli RM, Bandini G, Motta MR, Testoni N, Amabile M, Ottaviani E, Vianelli N, de Vivo A, Gozzetti A, Tura S, Cavo M. Molecular remission after allogeneic or autologous transplantation of hematopoietic stem cells for multiple myeloma. J Clin Oncol 2000;18(11):2273-81.

26. Willems $P$, Verhagen $O$, Segeren $C$, Veenhuizen $P$, Guikema J, Wiemer E, Groothuis L, Jong TB, Kok H, Bloem A, Bos N, Vellenga E, Mensink E, Sonneveld $\mathrm{P}$, Lokhorst $\mathrm{H}$, van Der Schoot $\mathrm{E}$, Raymakers R. Consensus strategy to quantitate malignant cells in myeloma patients is validated in a multicenter study. Belgium-Dutch Hematology-Oncology Group. Blood 2000;96(1):63-70.

27. Owen RG, Johnson RJ, Rawstron AC, Evans PA, Jack A, Smith GM Child JA, Morgan GJ. Assessment of IgH PCR strategies in multiple myeloma. J Clin Pathol 1996;49(8):672-5.

28. González D, van der Burg M, García-Sanz R, Fenton JA, Langerak AW, González M, van Dongen JJ, San Miguel JF, Morgan GJ. Immunoglobulin gene rearrangements and the pathogenesis of multiple myeloma. Blood 2007;110(9):3112-21.

29. González D, Balanzategui A, García-Sanz R, Gutiérrez N, Seabra C, van Dongen JJ, González M, San Miguel JF. Incomplete DJH rearrangements of the $\mathrm{lgH}$ gene are frequent in multiple myeloma patients: immunobiological characteristics and clinical implications. Leukemia 2003;17(7):1398-403.

30. Hadzidimitriou A, Stamatopoulos K, Belessi C, Lalayianni C, Stavroyianni N, Smilevska T, Hatzi K, Laoutaris N, Anagnostopoulos A, Kollia P, Fassas A. Immunoglobulin genes in multiple myeloma: expressed and non-expressed repertoires, heavy and light chain pairings and somatic mutation patterns in a series of 101 cases. Haematologica 2006;91(6):781-7.

31. Ferrero $S$, Drandi $D$, Mantoan $B$, Ghione $P$, Omedè $P$, Ladetto $M$. Minimal residual disease detection in lymphoma and multiple myeloma: impact on therapeutic paradigms. Hematol Oncol 2011;29(4):167-76.

32. Fenk R, Haas R, Kronenwett R. Molecular monitoring of minimal residual disease in patients with multiple myeloma. Hematology 2004;9(1):17-33.

33. Ladetto M, Pagliano G, Ferrero S, Cavallo F, Drandi D, Santo L, Crippa C, De Rosa L, Pregno P, Grasso M, Liberati AM, Caravita T, Pisani F, Guglielmelli T, Callea V, Musto P, Cangialosi C, Passera R, Boccadoro $M$, Palumbo A. Major tumor shrinking and persistent molecular remissions after consolidation with bortezomib, thalidomide, and dexamethasone in patients with autografted myeloma. J Clin Oncol 2010;28(12):2077-84. 
34. Schiller G, Vescio R, Freytes C, Spitzer G, Sahebi F, Lee M, Wu CH, Cao J, Lee JC, Hong CH, Lichtenstein A, Lill M, Hall J, Berenson R, Berenson J. Transplantation of CD34+ peripheral blood progenitor cells after high-dose chemotherapy for patients with advanced multiple myeloma. Blood 1995;86(1):390-397.

35. Ladetto $M$, Omedè $P$, Sametti $S$, Donovan JW, Astolfi $M$, Drandi D, Volpato F, Giaccone L, Giaretta F, Palumbo A, Bruno B, Pileri A, Gribben JG, Boccadoro M. Real-time polymerase chain reaction in multiple myeloma: quantitative analysis of tumor contamination of stem cell harvests. Exp Hematol 2002;30(6):529-36.
36. Martinelli G, Terragna C, Zamagni E, Ronconi S, Tosi P, Lemoli RM, Bandini G, Motta MR, Testoni N, Amabile M, Ottaviani E, Vianelli N, de Vivo A, Gozzetti A, Tura S, Cavo M. Molecular remission after allogeneic or autologous transplantation of hematopoietic stem cells for multiple myeloma. J Clin Oncol 2000;18(11):2273-81.

37. Lipinski E, Cremer FW, Ho AD, Goldschmidt H, Moos M. Molecular monitoring of the tumor load predicts progressive disease in patients with multiple myeloma after high-dose therapy with autologous peripheral blood stem cell transplantation. Bone Marrow Transplant 2001;(10):957-62.

\section{Supplementary data}

Table S1. Characteristics of used designed ASO primers for qualitative PCR detection of tumor-specific marker in MM.

\begin{tabular}{|c|c|c|c|c|c|c|}
\hline Patient & Clonality & Alelle & Primer & Sequence $\left(5^{\prime}-3^{\prime}\right)$ & Length (mer) & $\mathrm{T}_{\mathrm{m}}\left({ }^{\circ} \mathrm{C}\right)$ \\
\hline \multirow{2}{*}{1} & \multirow{2}{*}{ monoclonal } & \multirow{2}{*}{ IGHV2 } & forward & CACTTATTGATTGGGATGGT & 20 & 56 \\
\hline & & & reverse & TAGTCAAAGTGCAGTCGCT & 19 & 56 \\
\hline \multirow{2}{*}{2} & \multirow{2}{*}{ monoclonal } & \multirow{2}{*}{ IGHV3 } & forward & ATGAGTAGTGACGGGGGTA & 19 & 58 \\
\hline & & & reverse & TGTTGAAACTCTCGCACAGT & 20 & 58 \\
\hline \multirow{2}{*}{3} & \multirow{2}{*}{ oligoclonal } & \multirow{2}{*}{ IGHV3 } & forward & TAGTGGAGGTGAAACCCAAT & 20 & 58 \\
\hline & & & reverse & TGCTTCATCTCCAGTGCCA & 19 & 58 \\
\hline \multirow{2}{*}{4} & \multirow{2}{*}{ monoclonal } & \multirow{2}{*}{ IGHV4 } & forward & TTACACTGGGAGCACCAAC & 19 & 58 \\
\hline & & & reverse & AGATCGTAATCCGATCTCGC & 20 & 60 \\
\hline \multirow{2}{*}{5} & \multirow{2}{*}{ monoclonal } & \multirow{2}{*}{ IGHV3 } & forward & AAATCACCACCCACGGAGAT & 20 & 60 \\
\hline & & & reverse & TCCGACATCATACGCACAGT & 20 & 60 \\
\hline \multirow{2}{*}{6} & \multirow{2}{*}{ oligoclonal } & \multirow{2}{*}{ IGHV3 } & forward & AGCTATATCACATGATGGAAGT & 22 & 60 \\
\hline & & & reverse & TAGAACCCCCACTCCCGA & 18 & 58 \\
\hline \multirow{2}{*}{7} & \multirow{2}{*}{ oligoclonal } & \multirow{2}{*}{ IGHV1 } & forward & ACCCTAACGTTGGTGATACAA & 21 & 60 \\
\hline & & & reverse & TAATCATAGTAATCTCTCGCAC & 22 & 60 \\
\hline \multirow{2}{*}{8} & \multirow{2}{*}{ monoclonal } & \multirow{2}{*}{ IGHV3 } & forward & TACTGGTGGTGGTAGCACAT & 20 & 60 \\
\hline & & & reverse & CAATTATCATCCGCTTTCGC & 20 & 58 \\
\hline
\end{tabular}

Table S2. Standard curves parameters for RQ-PCR detection of tumor-specific marker in MM.

\begin{tabular}{cccccc}
\hline \multirow{2}{*}{ Patient } & Probe & Slope & Correlation coefficient & Quantitative range & Sensitivity \\
\hline \multirow{2}{*}{1} & ASO probe & -3.33 & 0.9988 & $1.00 \mathrm{E}-06$ & $1.00 \mathrm{E}-05$ \\
& RNase P & -3.56 & 0.9995 & $1.00 \mathrm{E}-06$ & $1.00 \mathrm{E}-05$ \\
2 & ASO probe & -3.18 & 0.9959 & $1.00 \mathrm{E}-06$ & $1.00 \mathrm{E}-06$ \\
& RNase P & -3.47 & 0.9991 & $1.00 \mathrm{E}-06$ & $1.00 \mathrm{E}-06$ \\
\multirow{2}{*}{4} & ASO probe & -3.33 & 0.9959 & $1.00 \mathrm{E}-05$ & $1.00 \mathrm{E}-05$ \\
& RNase P & -3.55 & 0.9985 & $1.00 \mathrm{E}-06$ & $1.00 \mathrm{E}-06$ \\
\multirow{2}{*}{5} & ASO probe & -3.07 & 0.9985 & $1.00 \mathrm{E}-04$ & $1.00 \mathrm{E}-04$ \\
& RNase P & -3.47 & 0.9990 & $1.00 \mathrm{E}-04$ & $1.00 \mathrm{E}-04$ \\
\multirow{2}{*}{8} & ASO probe & -3.35 & 0.9974 & $1.00 \mathrm{E}-06$ & $1.00 \mathrm{E}-05$ \\
& RNase P & -3.56 & 0.9995 & $1.00 \mathrm{E}-06$ & $1.00 \mathrm{E}-05$ \\
\hline
\end{tabular}

Table S3. Sequences of designed probes for RQ-PCR detection of tumor-specific marker in MM.

\begin{tabular}{clc}
\hline Patient & Sequence (5'-3') & Length (mer) \\
\hline 2 & 5'FAM: CTCTGGAGATGGTGAATCTGCC-TAMRA & 22 \\
4 & 5'FAM: CCGTGTTTGCGGCGGTCACA -TAMRA & 20 \\
5 & 5' FAM: GCCGTGTCCTCGACCCTCA-TAMRA & 19 \\
\hline
\end{tabular}




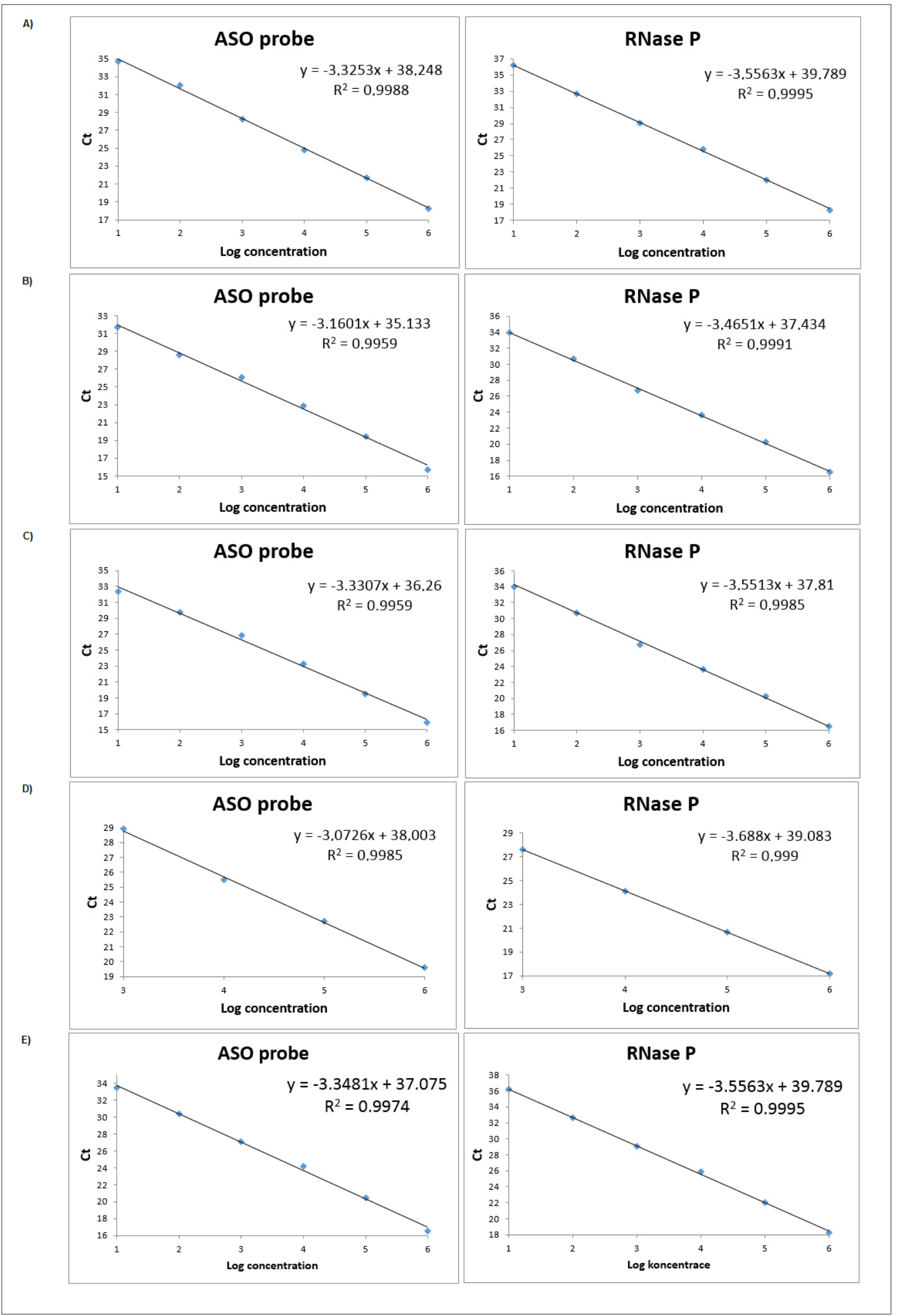

Fig. S1. Standard curves for quantitative real-time PCR detection of tumor-specific marker in MM.

A) Patient 1, B) Patient 2, C) Patient 4, D) Patient 5, E) Patient 8. 